\title{
Pomological and physicochemical characterization of Tamarindus indica (tamarind) grown in Florida ${ }^{1,2}$
}

\author{
Tomas Ayala-Silva ${ }^{3}$ *Hamide Gubbuk ${ }^{4}$, Michael Winterstein ${ }^{3}$ \\ and Guiliana Mustiga ${ }^{5}$
}

J. Agric. Univ. P.R. 100(2):141-154 (2016)

\begin{abstract}
Tamarind (Tamarindus indica L.) is a large evergreen tree belonging to the family Fabaceae (Leguminosae). Its fruits are eaten fresh, processed into a paste, used as a spice, made into a beverage, and used for tanning hides. Although this commercially important species has a wide geographical distribution, research on tamarind is sparse. Hence, the purpose of our research was to characterize 13 genotypes of tamarind at the Subtropical Horticultural Research Station in Miami, FL, USA, and to determine whether physical and pomological traits of this collection in fact reflect the genetic diversity within this fruit tree species. This work was conducted at SHRS in Miami, Florida. The pomological diversity of 13 tamarind genotypes was analyzed based on 18 qualitative and quantitative traits. Principal components analysis (PCA) conducted on quantitative traits showed an important degree of variability of about $72 \%$ for the first three principal components. A dendrogram was constructed based on average distances. Cluster analysis grouped all tamarind genotypes into three major clusters ('A', ' $B$ ' and ' $C$ '). Cluster ' $B$ ' includes the genotypes predominantly with brown to dark brown sweet and semi-sweet pulp and from South East Asia (Thailand and Philippines); the B cluster individuals were then grouped into sub-clusters 'B1', 'B2', 'B3' and 'B4'. Semi-sour genotypes were grouped in cluster ' $A$ ' and the sour genotype in cluster ' $C$ '. Cluster ' $B$ ' contained genotypes predominantly characterized by sweet, dark pulp, and smaller fruit size, while the sour genotypes were characterized by trees of sour pulp and from other regions (Australia, Brazil, India and the Caribbean). We detected moderate genetic diversity among these tamarind genotypes. This information could be used as a basis for selection during genetic improvement of tamarind genotypes.
\end{abstract}

Key words: tamarind, genetic diversity, principal component analysis, physicochemical characteristics

${ }^{1}$ Manuscript submitted to Editorial Board 14 July 2016.

${ }^{2}$ The authors would like to thank Dr. Stewart Reed, Dr. Seth Finley and Dr. Sadiye Gozlesci for their critical review of the manuscript.

${ }^{3}$ USDA-ARS, Subtropical Horticultural Research Station, 13601 Old Cutler Road, Miami, FL 33158. "Corresponding author. Email address: tomas.ayala-silva@ars.usda.gov

${ }^{4}$ Department of Horticulture, Faculty of Agriculture, Akdeniz University, Antalya 07058, Turkey.

${ }^{5}$ Mars Inc., 13601 Old Cutler Road, Miami, FL 33158. 


\title{
RESUMEN
}

\author{
Caracterización pomológica y fisicoquímica de Tamarindus indica \\ (tamarindo) en la Estación de Investigaciones en Horticultura Subtropical \\ en Miami, Florida
}

\begin{abstract}
El tamarindo (Tamarindus indica L.) es un árbol perenne de tamaño grande que pertenece a la familia Fabaceae (Leguminosae). Sus frutos se consumen frescos, procesados en una pasta, que se utiliza como especia, hecho en una bebida, y se utilizan para el curtido de pieles. A pesar de que estas especies comercialmente importantes tienen una amplia distribución geográfica, la investigación sobre el tamarindo es escasa. Por lo tanto, el propósito de nuestra investigación fue caracterizar 13 genotipos de tamarindo en el Repositorio Nacional de Germoplasma (SHRS, por sus siglas en inglés) en Miami, Florida, EE.UU., y determinar si los rasgos físicos y pomológicos de esta colección, de hecho, reflejan la diversidad genética dentro de esta especie de árboles frutales. Este trabajo se realizó en SHRS en Miami, Florida. La diversidad pomológica de 13 genotipos de tamarindo se analizó basado en 18 rasgos cualitativos y cuantitativos. Análisis de componentes principales realizados en los rasgos cuantitativos mostraron un importante grado de variabilidad de alrededor del $72 \%$ para los tres primeros componentes principales. Se construyó un dendrograma basado en distancias medias. El análisis de conglomerados agrupa todos los genotipos de tamarindo en tres grupos principales (' $A$ ', ' $B$ ' $y$ ' $C$ '). El grupo ' $B$ ' incluye los genotipos predominantemente de color marrón con pulpa dulce y semidulce marrón oscuro y del Sudeste de Asia (Tailandia y Filipinas); los individuos del grupo B fueron entonces agrupados en subgrupos 'B1','B2', 'B3', y 'B4'. Genotipos semi-agrio se agruparon en el grupo ' $A$ ' y el genotipo agrio en el grupo ' $C$ '. El grupo ' $B$ ' contenía una colección de genotipos predominantemente caracterizados por pulpa dulce y oscura, y el tamaño de los frutos más pequeños. Mientras que los genotipos agrios se caracterizan por árboles de pulpa ácida y de otras regiones (Australia, Brasil, India y el Caribe). Detectamos la diversidad genética moderada entre estos genotipos de tamarindo. Esta información podría ser utilizada como base para la selección durante el mejoramiento genético de los genotipos de tamarindo.
\end{abstract}

Palabras clave: tamarindo, diversidad genética, análisis de componentes principales, características físicoquímicas

\section{INTRODUCTION}

Tamarindus indica L. (tamarind) is a widely distributed tropical fruit tree found in Africa and Asia (Morton, 1987; El-Siddig et al., 1999; Janick and Paull, 2008; Ayala-Silva et al., 2010, 2013). Although its precise origin is unknown, most systematists consider tamarind to be indigenous to the drier grasslands of tropical Africa (Gunasena and Hughes, 2000; Ayala-Silva et al., 2013). However, it has long been naturalized in tropical Asia, the Caribbean, Mexico and Central America. Tamarind is highly cultivated throughout the tropics and is of economic importance throughout South-East Asia.

Tamarind is a long-lived, large, evergreen or semi-evergreen tree, 20 - to $30-\mathrm{m}$ tall with a trunk up to 1.5 to $2 \mathrm{~m}$ across, and up to $8 \mathrm{~m}$ in 
circumference (Morton, 1987; Parrotta, 1990; Karnataka, 2004; Janick and Paull, 2008). The trunk forks at about $1 \mathrm{~m}$ above ground and is often multi-branched, with branches spreading widely, drooping at the ends and often crooked but forming a spreading, rounded crown (NAS, 1979; Morton, 1987; Parrota, 1990; Janick and Paull, 2008). Tamarind, which originated in India, is the only genus belonging to the family Fabaceae (Leguminosae), and it is popularly known as 'Indian Date' (Morton, 1987). It is primarily valued for its fruits, especially the pulp, which is used for a wide variety of domestic and industrial purposes (Morton, 1987; Parrota, 1990; Janick and Paull, 2008; Ayala-Silva et al., 2013).

Tamarind is a highly cross-pollinated crop with a wide variation in the species; the total number of tamarind genotypes is estimated to be higher than 19,000 (Lewis et al., 2005; Naragajan et al., 1997). It is primarily propagated through seeds; thus, a wide range of heterozygosity is displayed for traits such as growth, yield, as well as quantity, quality, size, and shape of fruits.

Ripe tamarind fruit is popular, due to its acidic sweetness: it is used in desserts, such as jam, blended into juices or sweetened drinks or eaten as a snack; tamarind is also a natural laxative (Morton, 1987; Okello, 2010; Ayala-Silva et al., 2010). The pulp is also a rich source of carbohydrates and vitamins (Karnataka, 2004; Okello, 2010; Obulesu and Bhattacharya, 2011; Ayala-Silva et al., 2013; Gullipalli and Kasiviswanatham, 2013) and is widely used as a spice in the preparation of chutneys, sauces, soups, and certain beverages. Because it is very rich in ascorbic and tartaric acids, tamarind is also used as a food preservative (El-Siddig et al., 2006; Gullipalli and Kasiviswanatham, 2013). In addition, the pulp contains other organic acids, such as acetic acid, citric acid, formic acid, malic acid, and succinic acid. The pulp also contains amino acids; invert sugar ( 25 to $30 \%$ ); pectin; protein; fat; some pyrazines (trans-2-hexenal); and some thiazoles (2-ethylthiazole, 2-methylthiazole); lipids with fatty oils; and some keto acids (Bhadoriya et al., 2011).

From an agricultural perspective, tamarind is found in a wide range of environmental settings because it is highly tolerant to drought (Morton, 1987; Parrotta, 1990; Ayala-Silva et al., 2010, 2013). The main threats to tamarind production include exploitation for timber and charcoal production, expansion of agricultural activities and overgrazing.

Although tamarind has been domesticated for thousands of years, very little is known about its genetic improvement history. Farmers have generally selected genotypes from natural populations based on desirable fruit characteristics, such as fruit pulp quality. Variation in the vegetative 
growth characters, such as shoot length, root length, germination percentage, plant height, and pinnae per plant have been recorded for many cultivated genotypes (Bennet et al., 1997; Ayala-Silva et al., 2013).

More recently, economic pressure has prompted farmers to substitute local cultivars with new ones considered to be more productive. High genetic diversity has been reported across tamarind species; thus, there is no immediate cause for concern about genetic erosion, as long as agricultural practices permit regeneration of seedlings (ElSiddig et al., 1999, 2006; Muok and Alem, 2011; Bourou et al., 2012). The objectives of this study were to assess the genetic diversity of a set of tamarind genotypes and to establish relationships among them.

\section{MATERIALS AND METHODS}

The experiment was conducted at the National Germplasm Repository, Subtropical Horticulture Research Station (SHRS) in Miami, Florida, USA. The soil is a Krome type (loamy-skeletal, carbonic, hyperthermic Lithic Udorthents). Precipitation was $40.0 \mathrm{~cm}$ from January 2011 through February 2012, soil $\mathrm{pH}$ ranged from 7.5 to 8.0. Trees were fertilized twice a year with $\mathrm{N}-\mathrm{P}_{2} \mathrm{O}_{5}-\mathrm{K}_{2} \mathrm{O}(8-4-12)$ at a rate of 500 $\mathrm{g}$ per $2.54 \mathrm{~cm}$ of trunk diameter. Micronutrients applied with fertilizer included: $\mathrm{Mg}(4 \%), \mathrm{S}(0.56 \%), \mathrm{Mn}(1.01 \%), \mathrm{Cu}(0.05 \%), \mathrm{Fe}(1.36 \%)$, $\mathrm{Zn}(0.14 \%)$, and B $(0.06 \%)$. Weeds were controlled with glyphosate (Roundup Original $\mathrm{Max}^{\mathrm{TM}}$; St. Louis, MO) ${ }^{6}$ - as required.

TABLE 1.-List of tamarind ( $T$. indica) germplasm accessions, origin, and flavor.

\begin{tabular}{llll}
\hline Genotypes & Accession \# & \multicolumn{1}{c}{ Origin } & Flavor \\
\hline A & MIA 7865 & Philippines & semi-sour \\
Andrea & MIA 35187 & Thailand & sweet \\
B & MIA 25443 & Florida & sweet \\
C & MIA 26487 & Florida & sweet \\
D & MIA 25811 & Australia & semi-sour \\
E & PI 78534 & Philippines & sweet \\
F & PI 97789 & St Vincent Grenadines (India) & sour \\
G & MIA 26774 & Australia & semi-sour \\
H & PI 543772 & Bolivia (India) & sour \\
J & MIA35753 & California & sweet \\
I & MIA 11466 & Brazil (India) & sour \\
RFXY & PI 988884 & Netherlands/West Indies (India) & sour \\
T & MIA 36767 & Florida & sweet \\
\hline
\end{tabular}

${ }^{6}$ Mention of trade names or commercial products in this publication is solely for the purpose of providing specific information and doe not imply recommendation or endorsement by the U.S. Department of Agriculture. 
A list of tamarind accessions used in this study, as well as their origin/collection sources, are shown in Table 1. Fruit was harvested at maturity, when the size and color were appropriate for each cultivar, from April to June 2011 and 2012. Fifty fruits were harvested per tree. Fruit and seed length, diameter and weight, $\mathrm{Brix}, \mathrm{pH}$, and color (measured with a colorimeter) were recorded for each fruit harvested. Fruit and seed length and diameter were measured using a digital caliper (MycalLyte, Aurora, IL). Weight was measured using a Precision advanced scale (Ohaus® Model GT8000; Florham Park, NJ). Degrees Brix was determined by placing $1 \mathrm{~mL}$ of juice in a digital refractometer (SPER Scientific 300034, Scottsdale, AZ). Titratable acidity (expressed as malic acid) and $\mathrm{pH}$ were determined with a G20 compact titrator (Mettler Toledo, Schwerzenbach, Switzerland). For this purpose, tamarind pulp was extracted out of ripe pods, and three 20 -g samples were collected for each accession and blended with $40 \mathrm{~mL}$ of deionized water. Samples were then placed on a compact titrator and evaluated.

Fruit and seed color were measured with a Minolta Chroma Meter CR-400 portable colorimeter (Minolta Chroma Meter CR-400, Osaka, Japan) and Spectra Match software, set L, $\mathrm{a}^{*}, \mathrm{~b}^{*}$ mode. Fruit chromaticity was recorded in accordance with Commission Internationale d' Eclairage (1987), L, $\mathrm{a}^{*}, \mathrm{~b}^{*}$, which describes a uniform three-dimensional color space, where the $\mathrm{L}$ value corresponds to a black-white scale, and two chromatic components: $-\mathrm{a}^{*}$ for green to $+\mathrm{a}^{*}$ for red and $-\mathrm{b}^{*}$ for blue to $+\mathrm{b}$ for yellow. In addition, $\mathrm{C}^{*}$ (Chroma; saturation level of $h^{\circ}$ ) and $h^{\circ}$ (hue angle; $0^{\circ}=$ red, $90^{\circ}=$ yellow, $180^{\circ}=$ green, $270^{\circ}=$ blue) were obtained using CIELAB color values as $\mathrm{C}^{*}=\left(\mathrm{a}^{*} 2+\mathrm{b}^{* 2}\right)$ and $\mathrm{h}=\arctan$ $\left(b^{*} / a^{*}\right)$.

The three replicates consisted of three samplings per tree of 15 fruits each for a total of 45 fruits. All analyses were conducted using SAS 9.2 software (SAS Institute, Inc., Cary, NC, 2002-2004). Principle coordinate (PC) analysis was carried out using the PRINCOMP procedure and the accessions were plotted on the first 3 PCs.

\section{RESULTS AND DISCUSSION}

\section{Physical characteristics}

The most significant fruit quality parameters of the tamarind genotypes are shown in Tables 2 to 5 . Pod/fruit weight ranged from $7.97 \mathrm{~g}$ (genotype C) to $20.21 \mathrm{~g}$ (genotype RFXY) with an average of $17.65 \mathrm{~g}$ in the sour genotypes and from $7.97 \mathrm{~g}$ (genotype C) to $15.5 \mathrm{~g}$ (genotype $\mathrm{G}$ ) with an average of $15.15 \mathrm{~g}$ in the sweet genotypes (Table 2). Average pod length and diameter were $96.0 \mathrm{~mm}$ and $22.46 \mathrm{~mm}$, respectively in 


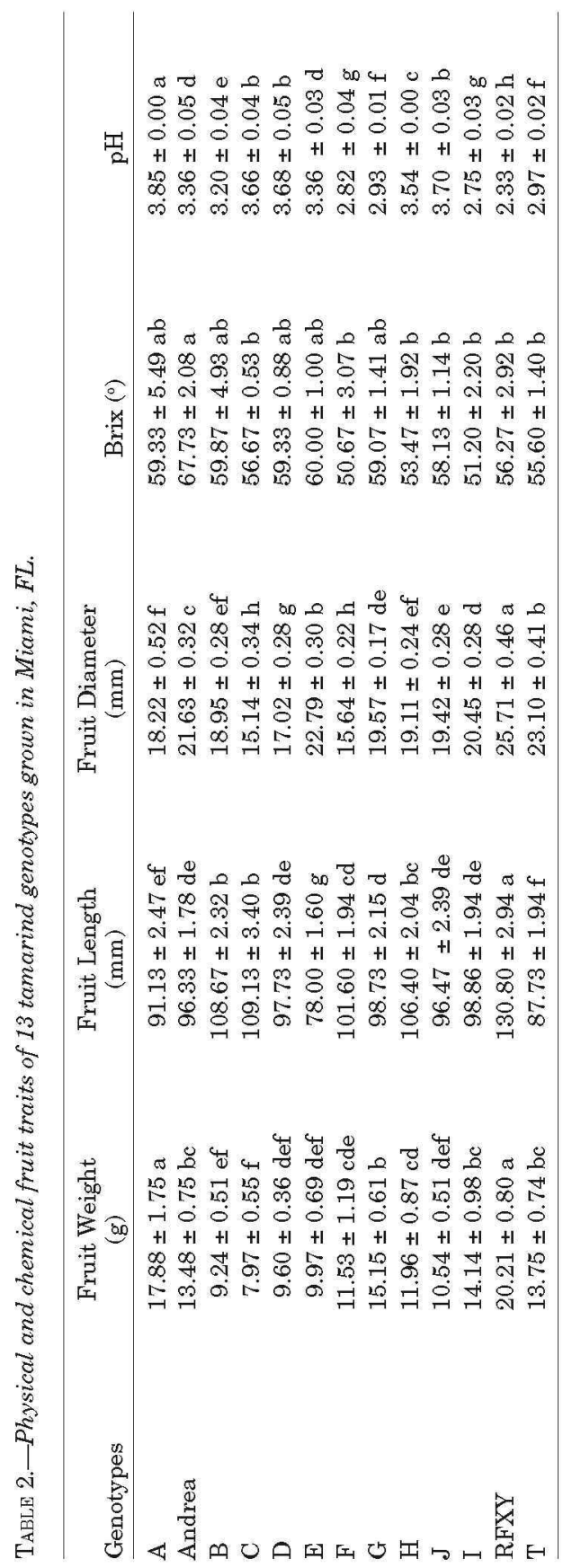


TABLE 3.-Seed weight, length, and diameter of 13 tamarind genotypes grown in Miami, FL.

\begin{tabular}{lccc}
\hline Genotypes & $\begin{array}{c}\text { Seed Weight } \\
(\mathrm{g})\end{array}$ & $\begin{array}{c}\text { Seed Length } \\
(\mathrm{mm})\end{array}$ & $\begin{array}{c}\text { Seed Diameter } \\
(\mathrm{mm})\end{array}$ \\
\hline A & $0.54 \pm 0.03 \mathrm{~cd}$ & $11.03 \pm 0.16 \mathrm{~cd}$ & $8.78 \pm 0.33 \mathrm{def}$ \\
Andrea & $0.55 \pm 0.01 \mathrm{~cd}$ & $11.10 \pm 0.16 \mathrm{~cd}$ & $10.61 \pm 0.30 \mathrm{bc}$ \\
B & $0.50 \pm 0.02 \mathrm{~d}$ & $9.67 \pm 0.21 \mathrm{ef}$ & $10.33 \pm 0.29 \mathrm{c}$ \\
C & $0.30 \pm 0.02 \mathrm{f}$ & $8.78 \pm 0.20 \mathrm{~g}$ & $8.24 \pm 0.42 \mathrm{ef}$ \\
D & $0.37 \pm 0.02 \mathrm{e}$ & $9.29 \pm 0.11 \mathrm{fg}$ & $8.42 \pm 0.21 \mathrm{def}$ \\
E & $0.57 \pm 0.03 \mathrm{c}$ & $11.41 \pm 0.16 \mathrm{bc}$ & $10.82 \pm 4.40 \mathrm{bc}$ \\
F & $0.54 \pm 0.02 \mathrm{~cd}$ & $11.51 \pm 0.21 \mathrm{bc}$ & $9.28 \pm 0.28 \mathrm{~d}$ \\
G & $0.52 \pm 0.02 \mathrm{~cd}$ & $10.76 \pm 0.19 \mathrm{~d}$ & $7.99 \pm 0.37 \mathrm{f}$ \\
H & $0.51 \pm 0.02 \mathrm{~cd}$ & $9.77 \pm 0.17 \mathrm{ef}$ & $10.48 \pm 0.43 \mathrm{c}$ \\
J & $0.55 \pm 0.01 \mathrm{~cd}$ & $10.53 \pm 0.15 \mathrm{e}$ & $9.18 \pm 0.28 \mathrm{de}$ \\
I & $0.63 \pm 0.02 \mathrm{~b}$ & $11.15 \pm 0.28 \mathrm{~cd}$ & $10.52 \pm 0.33 \mathrm{c}$ \\
RFXY & $0.90 \pm 0.02 \mathrm{a}$ & $14.13 \pm 0.18 \mathrm{a}$ & $11.98 \pm 0.25 \mathrm{a}$ \\
T & $0.67 \pm 0.01 \mathrm{~b}$ & $11.82 \pm 0.16 \mathrm{~b}$ & $11.54 \pm 0.23 \mathrm{ab}$ \\
\hline
\end{tabular}

the sour genotypes and $102.0 \mathrm{~mm}$ and $17.68 \mathrm{~mm}$ in the sweet genotypes. Fruit diameter was the highest $(25.71 \mathrm{~mm})$ in genotype RFXY and lowest in genotypes $\mathrm{C}$ and $\mathrm{F}(15.14 \mathrm{~mm}, 15.64 \mathrm{~mm})$.

The highest Brix was in genotype Andrea and obtained the lowest in genotype $\mathrm{F}$ (Table 2); while the highest $\mathrm{pH}$ was reported in genotype A and the lowest (a characteristic of sour varieties) in genotype RFXY (Table 2). There were significant differences among genotypes for seed parameters. Seed weight, length and diameter were highest in RFXY and lowest in genotype C (Table 3). Average seed weights were $0.67 \mathrm{~g}$ and $0.46 \mathrm{~g}$, in the sour and the sweet genotypes, respectively.

We also detected significant variation in shell and pulp color $\mathrm{L}, \mathrm{a}^{*}$, $\mathrm{b}^{*}$, chroma, and hue among the various accessions (Tables 4 and 5). Such variation is possibly the result of genetic differences. The highest $\mathrm{L}$ value for shell color was found in genotypes RFXY and $\mathrm{J}$, and the lowest was in genotype A, Andrea, D and E (Table 4). The fruit shell color of these genotypes was grayish brown or brown; whereas pulp color was brown or reddish-brown, respectively. Other genotypes (B group) had dark brown fruit shell and pulp.

The luminescence $(\mathrm{L})$ parameter was different between genotypes $\mathrm{H}$ and $\mathrm{G}$ but not different between genotypes RFXY and $\mathrm{H}$, indicating the lighter pulp color is observed for genotype $\mathrm{H}$ (Table 5). However, parameters $a^{*}, b^{*}$ and $C^{*}$ for genotype RFXY pulp color were higher than for genotype $\mathrm{H}$ showing RFXY has lighter pulp color than $\mathrm{H}$.

Principal component analysis (PCA) is a technique used to emphasize variation and bring out strong patterns in a dataset. PCA 


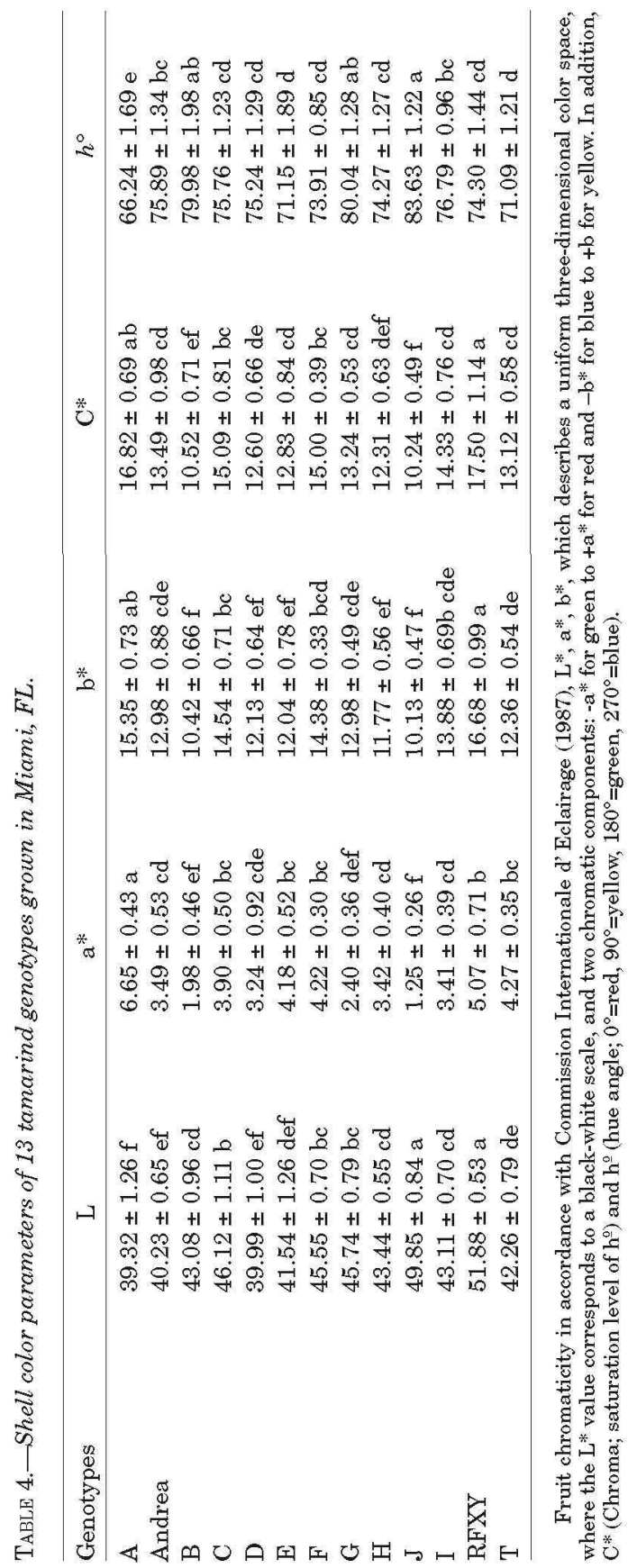




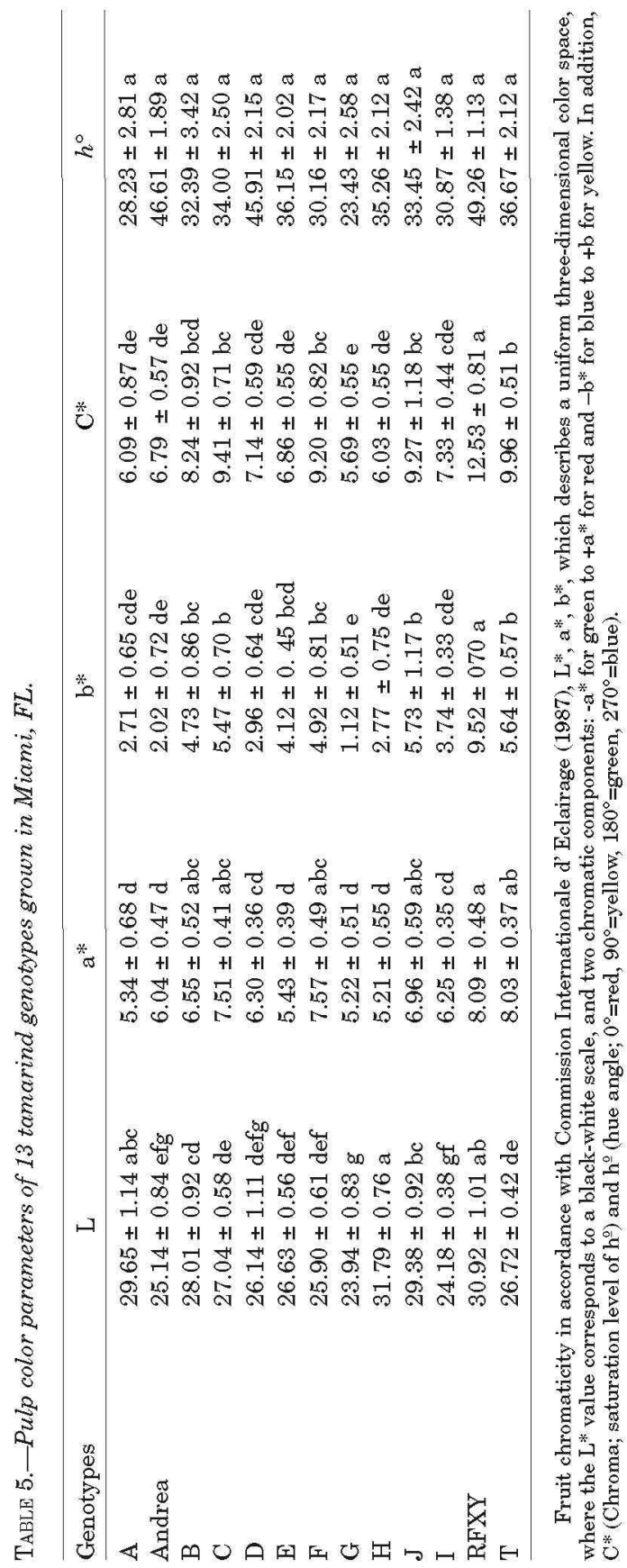


arranges data by major axes based on measured variables. The first principal component (PC1) is the linear combination of $\mathrm{x}$-variables that has maximum variance (among all linear combinations), so it accounts for as much variation in the data as possible. The second principal component (PC2) is the linear combination of $\mathrm{x}$-variables that accounts for as much of the remaining variation as possible, with the constraint that the correlation between the first and second component is 0 , and the third principal component (PC3) is a linear combination that accounts for as much of the remaining variation as possible, and they are not correlated with the other principal components (PCA estimates the correlation structure of the variables). The importance of a variable in a principal components model is indicated by the size of its residual variance. This is often used for variable selection.

The results of PCA for physicochemical characteristics are presented in Table 6. The PCA of the phenotypic traits was run to better understand relationships between the observed phenotypes as a result of underlying genetics and the interaction with the environment, which attribute to the genetic diversity of the cultivars. The PCA is useful in understanding which characteristics tend to

TABLE 6.-Coefficients and eigenvalues for the first three principal components $(P C)$ of the $P C A$ for fruit and seed traits of 13 tamarind genotypes grown in Miami, FL.

\begin{tabular}{lrrr}
\hline Variable & PC1 & PC2 & PC3 \\
\hline Fruit length & 0.21 & 0.21 & -0.24 \\
Fruit weight & 0.26 & -0.24 & 0.07 \\
Fruit diameter & 0.24 & -0.02 & 0.07 \\
Seed weight & 0.25 & 0.03 & 0.38 \\
Seed diameter & 0.33 & -0.11 & 0.18 \\
Seed length & 0.33 & -0.01 & 0.25 \\
Brix & -0.10 & -0.08 & 0.34 \\
pH & -0.27 & -0.08 & -0.07 \\
Flesh color L & 0.23 & 0.25 & -0.20 \\
Flesh color a* & 0.29 & 0.24 & -0.11 \\
Flesh color b* & 0.13 & 0.05 & -0.05 \\
Flesh color Chroma & 0.29 & 0.26 & -0.14 \\
Flesh color hue & 0.16 & 0.06 & 0.21 \\
Shell color L & 0.18 & -0.43 & -0.17 \\
Shell color a* & 0.24 & -0.27 & -0.31 \\
Shell color b* & 0.21 & 0.34 & -0.17 \\
Shell color Chroma & 0.24 & -0.31 & -0.29 \\
Shell color hue & -0.01 & 0.45 & 0.06 \\
Eigienvalues & 7.03 & 3.51 & 2.35 \\
Proportion & 0.39 & 0.20 & 0.13 \\
\hline
\end{tabular}


vary together and the direction in which they vary. The difference between PC1, PC2, and PC3 is that PC1 accounts for as much as possible of the variation in the data, $\mathrm{PC} 2$ accounts for the second largest variation, and PC3 for the third largest variation. The total of the first three PCA capture $72 \%$ of the variability. The first PC made up $39.0 \%$ of the variability of the data and was positively correlated with most of the phenotypes, namely, seed diameter (0.33), seed length (0.33), flesh color $\mathrm{a}^{*}(0.29)$, flesh color chroma $(0.29)$, fruit weight (0.26), and negatively correlated with $\mathrm{pH}(-0.27)$. This finding indicates that genotypes with big seeds will tend to have fruits that weigh more, have higher values for flesh color, and a low $\mathrm{pH}$. If the $\mathrm{pH}$ is high, then the positively correlated traits for PC1 will tend to have lower values (such as smaller seeds and fruits).

The second PC accounted for $20 \%$ of the additional variability not explained by PC1. Shell color hue (0.45), shell color $b^{*}(0.34)$, flesh color chroma (0.26), and flesh color L $(0.25)$ were positively correlated with PC2. Shell color L (-0.43), shell color chroma (-0.31), shell color $\mathrm{a}^{*}(-0.27)$ and fruit weight $(-0.24)$ decreased in PC2. The third principal component accounted for $13.0 \%$ of the total variability, and it increases seed weight (0.38) and Brix (0.34) and decreases with shell color $\mathrm{a}^{*}(-0.31)$.

The genotype RXYZ deviates significantly from the other cultivars, likely because it had the highest average value for weight $(20.21 \mathrm{~g})$, fruit length $(130.80 \mathrm{~mm})$ and diameter $(25.71 \mathrm{~mm})$. The lowest $\mathrm{pH}$ (2.33) was negatively correlated in all three components. Seed length, weight and diameter, fruit flesh color $\left(a^{*}, b^{*}\right.$ and $\left.C^{*}\right)$, and shell color values $\left(\mathrm{a}^{*}, \mathrm{~b}^{*}\right.$ and $\left.\mathrm{C}^{*}\right)$ were the most important variables of PC1. Values L, $\mathrm{a}^{*}$ and $\mathrm{C}^{*}$ for fruit flesh, and shell color hue, shell color $\mathrm{L}$, and flesh color $\mathrm{a}^{*}$ and $\mathrm{b}^{*}$ had the greatest effect on PC2. The flesh color hue, Brix, seed length, weight and diameter were the significant parameters included in PC3 (Table 6).

A dendrogram of the 13 tamarind genotypes was constructed using a cluster procedure. Cluster analysis using the unweighted pair group method with arithmetic mean (UPGMA), based on morphological distance analysis, showed that the 13 genotypes could be divided into three main groups: A, B and C (Figure 1).

Group A included three accessions and could be further separated into two subgroups that were found to have different morphological characteristics. Subgroup A1 included the genotypes E and T, with similar Brix, color $\mathrm{a}^{*}$ and chroma, fruit diameter, seed diameter and seed length. Whereas tree $\mathrm{A}$ separated from $\mathrm{E}$ and $\mathrm{T}$ with higher fruit weight and length, a higher $\mathrm{pH}$ and pulp color. This group clustered together perhaps because they originated from the 


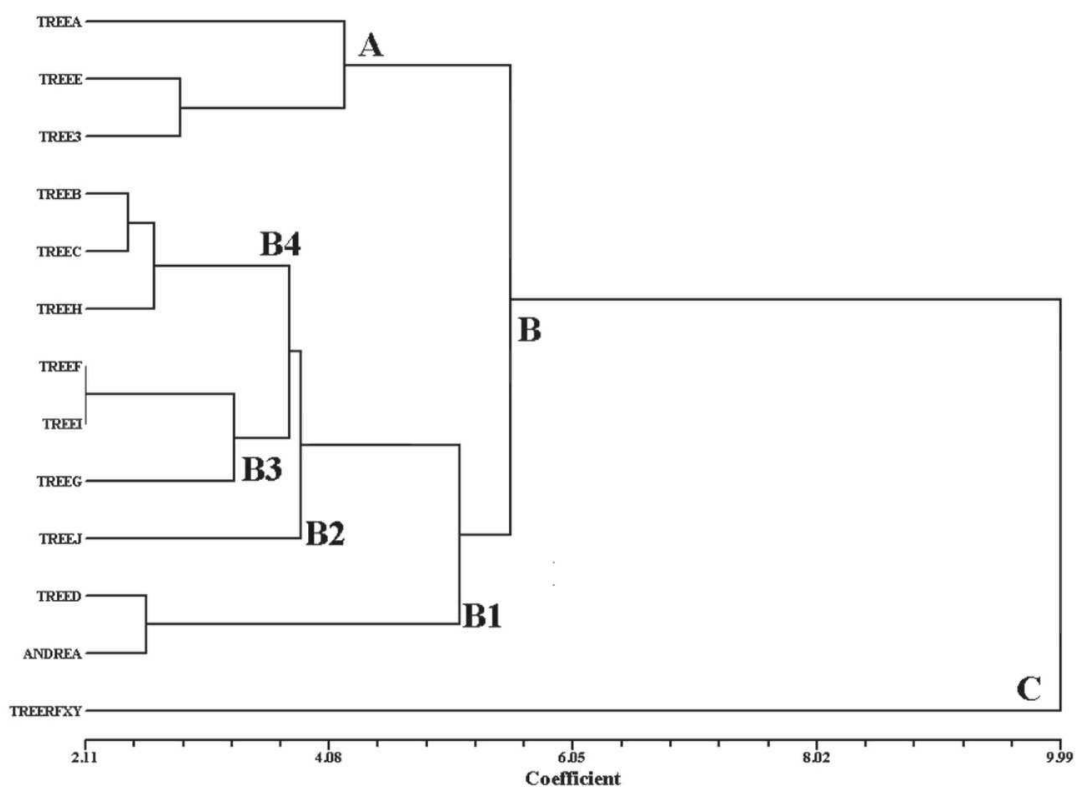

FIGURE 1. UPGMA dendrogram based on morphological distances of 13 tamarind genotypes grown in Miami, FL.

same region (Philippines). Although tree $\mathrm{T}$ is labeled as originating in Florida, the seeds were brought from the Philippines.

Group B included nine accessions and subdivided into four subgroups. Subgroup B1 included accessions (D and Andrea) that were characterized by trees of similar color characteristics $\left(\mathrm{L}, \mathrm{a}^{*}, \mathrm{~b}^{*}, \mathrm{C}^{*}\right.$ and $h$ ) of shell and pulp, but with significant differences in fruit and seed weight, length and diameter. By contrast, subgroup B2 separated by itself and is characterized by small fruit size, high Brix content and seed weight. Subgroup B3 resolved into two minor clusters (Figure 1). Subclusters $F$ and $I$, and $G$ are characterized by similar flesh and color ( $\mathrm{L}, \mathrm{a}^{*}, \mathrm{~b}^{*}, \mathrm{c}^{*}, h$ and $\left.\mathrm{C}^{*}\right)$, seed length, Brix and $\mathrm{pH}$. The genotypes of subgroup B4 were segregated further into two minor clusters ( $\mathrm{B}$ and $\mathrm{C}$, and $\mathrm{H}$ ) that were characterized by a high $\mathrm{L}, \mathrm{a}^{*}$ and $\mathrm{b}^{*}$ and similar flesh color hue, seed weight and length, Brix and $\mathrm{pH}$.

Group C (RFXY), however, segregated into a single cluster characterized by a higher fruit and seed weight, length and diameter, lowest $\mathrm{pH}$, and highest pulp and flesh $\mathrm{L}, \mathrm{a}^{*}, \mathrm{~b}^{*}$, chroma and hue. Moreover, Brix was not significantly different from Andrea. 
In conclusion, the PCA and cluster analysis captured $72 \%$ of the variations existing in the 13 tamarind accessions considered in this work. It may be possible with proper management and utilization of some of these accessions (i.e., RFXY, T, A, Andrea and G) to exploit these traits. This may bring a difference in fruit size, color, flavor and sugar content. Hence, this information should be useful for tamarind germplasm selection, in the determination of genetic relationships among genotypes (e.g., between sweet and sour trees), and for more efficient management of tamarind genetic resources by farmers and researchers.

\section{LITERATURE CITED}

Ayala-Silva, T., R. J. Schnell, A. W. Meerow, M. Winterstein and G. Gordon, 2010. 'Andrea' (Miami Sweet) Tamarind. Acta Hort. 935: 41-45.

Ayala-Silva, T., H. Gubbuk and G. Gordon, 2013. Breaking seed coat dormancy with physical and chemical methods in tamarind (Tamarindus indica L.) seeds. J. Agric. Univ. P.R. 97 (1-2): 87-96.

Bennet, S.S.R., A. Durai, A. Nicodemus, K. Gireesan, B. Nagarajan and M. Varghees, 1997. Genetic improvement of Tamarindus indica L. for increased productivity. Proceedings of National Symposium on Tamarindus indica L. Tirupati, Andhra Pradesh, India. pp 47-50.

Bhadoriya, S. S., A. Ganeshpurkar, J. Narwaria, G. Rai and A. P. Jain, 2011. Tamarindus indica: Extent of explored potential. Pharmacogn. Rev. 5: 73-71.

Bourou, S. C., S. C. Bowe, M. Diouf and P. Van-Damme, 2012. Ecological and human impacts on stand density and distribution of tamarind (Tamarindus indica L.) in Senegal. Afr. J. Ecol. 50: 253-265.

Commission Internationale de L'Éclairage, 1987. Colorimetry, 2nd ed., Publication CIE No. 15.2, 78.pp. Central Bureau of the CIE, Vienna.

El-Siddig, K., G. Ebert and P. Luedders, 1999. Tamarind (Tamarindus indica L): A review on a multipurpose tree with promising future in the Sudan. J. of Appl. Bot.73: $5-6$.

El-Siddig, K., J. T. Williams, H. P. M. Gunasena, B. A. Prasad, D. K. N. G. Pushpakumara, K. V. R. Ramana and P. Vijayanand, 2006. Tamarind fruits for the future. International Centre for Underutilised Crops, 188 Southampton, UK: University of Southampton.

Gullipalli, S. and V. Kasiviswanatham, 2013. Extraction of tartaric acid from tamarind pulp and analysis of the acid composition in leaves. International Journal of Students Research in Technology \& Management Vol (1) 5:478-488.

Gunasena, H. P. M. and A. Hughes, 2000. Tamarind, Tamarindus indica L., International Centre for Underutilised Crops. South Hampton, UK. 169 pp.

Janick, J. and R. E. Paull, 2008. Tamarind. In: The Encyclopedia of Fruit \& Nuts: CABI Publisher; First edition, pp 400-405. ISBN-13: 978-0851996387.

Karnataka, J., 2004. Evaluation of elite clones of tamarind. Journal of Agricultural Sciences 17 (3): $512-514$.

Lewis, G., B. Schrire, B. Mackinder and M. Lock (eds.), 2005. Legumes of the World. Royal Botanic Gardens, Kew.

Morton, J., 1987. Tamarindus indica. Fruits of Warm Climates. Creative Resources Systems Inc. Miami, Florida, 115-121.

Muok, B. O. and S. Alem, 2011. Tamarindus indica, tamarind. Conservation and Sustainable Use of Genetic Resources of Priority Food Tree Species in sub-Saharan Africa. Bioversity International (Rome, Italy). 
Nagarajan, B., A. Nicodemus, A. K. Mandal, R. K. Verma, K. Gireesan and N. P. Mahadevan, 1997. Phenology and controlled pollination studies in Tamarind. Silvae Genetica 47: 237-241.

NAS, 1979. Tropical Legumes: Resources for the Future. National Academy of Science, Report of an Ad Hoc Panel of the advisory committee on technology innovation.

Obulesu, M. and S. Bhattacharya, 2011. Color changes of tamarind (Tamarindus indica L.) pulp during fruit development, ripening, and storage. Int. J. Food Prop. 14: (3) $538-549$, doi: $10.1080 / 10942910903262129$.

Okello, J., 2010. Morphological and Nutritional Characteristics of Tamarindus indica (Linn) Fruits. 63 pp. Unpublished master's thesis, Makerere University, Uganda.

Parrotta, J. A., 1990. Tamarindus indica L. (Tamarind). SO-ITF-SM-30 June, US Department of Agriculture (USDA) Forestry Service, Rio Piedras, Puerto Rico: pp 1-5. 